\title{
"Blurred Lines”: Robin Thicke and Madonna Ciccone between Madonna and Whore
}

\author{
Hartmut Heep \\ The Pennsylvania State University, U.S.A
}

\begin{abstract}
Robin Thicke's song "Blurred Lines” rekindled the debate about women who must choose an existence as Madonna or as whore. Biblical archetypes, such as Eve and Mary, are normative role models for women, even within secular societies. This study follows a pre-Fall Eve, who experiences shameless sexual pleasures, to a post-Fall shamed Eve, to the Virgin Mary, who is mother but virgin. Robin Thicke’s video "Blurred Lines,” and Madonna Ciccone's various videos reclaim sexual pleasures for women outside of sin. Close readings of several visual texts will show that how meaning is redistributed among signifieds by deconstructing and redefining conventional signifiers, such as virgin and whore.
\end{abstract}

Keywords : gender studies, religious studies, popular culture, feminist theory, social theory

\section{Introduction}

In their introductory essay "Accounting for Sexual Meanings" Sherry Ortner and Harriet Whitehead (1981) it shows how women are androcentrically defined in terms of nature, domestic, and self-interest as opposed to culture, public, and social good. The female existence arises out of serving in these subsidiary roles in which women fulfill male needs and desires. The basis for this arbitrary arrangement is the Bible. The Virgin Mary, as the archetype of mother but virgin, and Eve, in her pre-and post-Fall duality, are the accepted norms for the female existence in Christian societies. The artist Madonna Ciccione, and the video "Blurred Lines" liberate women from a blurred choice between virgin and whore.

The elimination of male-female biology, as the sole difference between men and women, has forced secular societies to invent elaborate mechanisms to assign masculine and feminine roles. In order to grant privileges to men, women must be suppressed. Based on the fact that power, according to Anthony Ocampo (2012), is negotiated between the genders, men have dominated women (p. 450). Consequently, the first book of female suppression is Genesis. In the beginning "God created man in his own image, in the image of God he created him”; “To the woman he said, 'I will greatly multiply your pain in childbearing; in pain you shall bring forth children, yet your desire shall be for your husband, and he shall rule over you’”. God's biological understanding of Eve serves as justification for the restrictions of women within a Biblical based world. Jesus' selection of only men as disciples, according to Cynthia Stewart (n. d.), remains the theological legitimization for keeping women excluded.

Hartmut Heep, Associate professor of German and Comparative Literature ,The Pennsylvania State University.

Correspondence concerning this article should be addressed to 200 University Drive, Schuylkill Haven, PA 17972-2208. Email: hxh17@psu.edu. 


\section{Discussion}

A solid body of research on gender has been created in the fields of feminist theory, sociology and psychology; however, in order to capture current gender perceptions, this study also includes popular voices outside the academic arena, such as Marcel. In a recent post on "Creative Minority Report" Marcel(2010) puts the end of a God given female suppression in a Biblical perspective:

“Adam was given the commission by God 'to cultivate and care for' the Garden of Eden and all that was in it. Adam messed up soon after. He fails to protect his wife, because he is a coward. He then blames his wife and in doing so he relinquishes his masculinity. Notice that after giving up his masculinity he quickly falls into lusting after his wife, which is why they have to cover themselves—-to protect themselves from the lust of the other” .

Marcel's argument is essential for defining a basic male-female gender model: Adam does not take responsibility for his action of eating the apple; instead, he blames Eve for giving it to him. Blaming Eve is a gender mechanism in traditional Judeo-Christian societies, in which Eve's action serves as justification for suppressing women. Eve is seen as a temptress and the bearer of sin, whereas Adam becomes the victim of her evil action. Such moral judgment has fundamental ramifications for all aspects of life in which women are presented with fewer legal, social, and economic opportunities and rights. As long as Eve is a core value of a secular, English-speaking society, women, although unspoken but perhaps subconsciously, will be associated with evil. Adam remains in control, but with the lack of responsibility for his actions, according to Marcel: "The modern man has also relinquished his masculinity by failing to have self-control. The modern man is an emasculated macho fool who has given in to his pornified passions and lives a sterile and contracepted life- he bears no fruit, literally and figuratively” (Marcel, 2010).

Christian femininity is based on Mary, the mother but virgin. Whereas Eve is claimed by the Jewish and Christian religions alike, the Virgin Mary, although Jewish, gained social status only within the Christian world. Hence this study differentiates between a Biblical reference, including an orthodox understanding of Christianity and Judaism, and references to the Virgin Mary, which applies only to the Christian interpretation of the Bible. Thus, for Beatriz Morales, the Virgin Mary is "a mediator between individuals, groups, nations and God" (Morales, 1994, p. 193), in other words, Mary is the mother of the entire Christian civilization. Fernando Ortiz calls this concept Marianismo. Ortiz (2012) argues that:

"Marianismo is a female corollary to machismo, and it is a cultural or religious description of the ideal woman as self-abnegating mother. This concept is explained by the veneration of the Virgin Mary, the ideal symbol of virgin and mother".

Despite the elimination of sexual pleasure as virgin mothers, Christianity offered women social gratification, albeit only as mothers and, post-defloration, as chaste wives and bearers of those traditions that limit them. Ortiz (2012) notes that: Marianismo "exalts femininity and childbearing capacity by emphasizing women's fated long-suffering or hembrismo, as well as the qualities of obedience, submission, fidelity, meekness, and humility". According to the Spanish English Dictionary on the website www.wordreference.com, the term hembra provides the following meaning: "biological female or colloquial woman". We understand "hembra" as female in her reproductive, not sexual, role. Female biology is deeply written into the Christian existence and the stereotyped behavior that is based on conviction.

Females and males both have sacrificed their association with sexuality. Whereas the female is relegated to biology, it seems that the male is identified as breadwinner and best friend or partner to his female mate. The 
Biblical Adam had already made a choice against the sexual Lilith, as described in the Jewish Kabbalah, in favor of Eve, a woman he could have presented proudly to his own mother. Lilith, the whore, is replaced by Eve, who might have been a whore before the Fall, but is transformed into a mother after the Fall. This transformation is accompanied by shame, chastity, and the loss of open sexual pleasures. Mary, eventually, ascends to virgin mother, eliminating any hint of sexuality, a concept we previously encountered as Marianismo. Hence, Adam exchanges his biological maleness for a social masculinity. At least Adam experienced non-procreative sexuality with Lilith, the whore, and a pre Fall Eve as whore. Joseph is left with his asexual, virgin mother girlfriend Mary. But Mary, and with her the Christian female prototype, is not only virtuous or asexual, she is also naturally pious. Men on the other hand, according to Linda Brannon(2012), “...were not naturally as religious and thus not naturally as virtuous as women” ( p. 161). The natural inability to be virtuous allows men to seek a more sexual and libidinal existence, often in the socially accepted, even encouraged, extra marital affairs in which men prove their virility. A biologically based femininity allows some women to regain a pre-Mary sensuality. If women emulate a tempting, pre-Fall, seductive Eve in high heels, micro miniskirts, and a deep cleavage, men can show their primary sexual characteristics, such as sculptured chest, as well as muscled and tattooed arms, to other competing males. The pleasure of pre-marital play of sensuality, however, comes at a price for Christian women who are relegated to Biblical conventions, once deflowered.

Monogamy and chastity are the price Christian women have to pay for social acceptance as virgin mothers by negating the pleasure of sex and by preserving the power of the hymen as their most valuable social contribution. The woman's exchange of virtue for social acceptance is based on marriage as an institution. Women give up chastity, in order to gain their husband's name and entry into a different caste or social class, while documenting their newly acclaimed status with an engagement ring that reflects their husband's economic status. Husbands, through marriage, gain social stability, and the continuation of his name through his children. Consequently, Adam, who is partnered with the post-Fall mother Eve, has to transfer his sexuality into pornography and the fading memory of his sexual Ex, Lilith. But as Mary, the virgin mother and ultimate generation of Christian gender models, ceases to be the object of sexual lust, Joseph is left without a pornofied version of femininity, such as the whore, who cannot be virgin and should not be mother.

The explicit sexual choreography of a pre-Fall Eve in the video clip "Blurred Lines" has become the center of a gender controversy. "Blurred Lines" is a single from the album Blurred Lines by Robin Thicke. The song has been a worldwide hit since its release on March 26, 2013, climbing to the top of the pop charts around the world. This ubiquitous summer 2013 song has sold over five million copies in the US, according to Wikipedia. The catchy tune with the leitmotiv "I know you want it" comes in a general version and in an unrated version with topless dancers. Controversy over the unrated video erupted by June 2013. One of the first critical voices to label the video as misogynistic and demeaning was Katie Russell, the spokeswoman for the British organization Rape Crisis. "Both the lyrics and the video seem to objectify and degrade women, using misogynistic language and imagery that many people would find not only distasteful or offensive but also really quite old fashioned” (Chen, 2013). Gary Mason reads the unrated video version as follows: Mr. Thicke and two male collaborators, fully clothed, sing in the company of three female models who are topless and prance around like witless, voiceless sex dolls. The implicit message is that they're there for the amusement of the men, to serve whatever fantasies they may be harbouring. The women have no say. The men know what they want(Mason, 2013). 
Soon after, the video was banned by the University of Edinburgh, Derby, West Scotland, Kingston, and Leeds in the UK. According to Sean Michaels "the video promotes an unhealthy attitude towards sex and consent” (Michaels, 2013).

Similar criticism has not come from Continental Europe or Australia, where the video has been equally successful. According to a chart in Wikipedia, the video peaked in Japan 22 times, the Czech Republic and Hungary 10 times, in Finland nine times, and Sweden six times. The political systems in these countries exclude Biblical references more strictly from public opinions and moral judgments. It appears that American and British criticism is rooted in a Christian understanding of the post-Paradise female as chaste and shameful. The video, however, rejects those conventions. First, the female models in the unrated version are not nude but topless. Women sunbathe topless on many secular European beaches without shame or sexual harassment. Christian women, however, have to cover up, since nudity seems to be a reminder of Eve's evil action as temptress. Consequently, nudity is intricately connected to sin.

A visual reading of the video is reminiscent of a playful Eve prior to the Fall. Unaware and unashamed of their toplessness, the dance models walk on the set freely. At times, the walk mimics the presence of a catwalk but lacks a seductive aura. Gary Mason's argument of viewing the dancers as "sex dolls" (Mason, 2013) is based on the voyeuristic, male gaze. Women dress, and ought to undress, themselves for themselves, not for men. The topless choreography, while sensuous, does not permit men to include or even force their sexual fantasies on the dancers. Sexually explicit gestures are related to props, such as the sitting on a phallic stool and bicycle. All props are white, including the clunky plateau shoes of the female models and the white lingerie, thus suggesting the innocence of the girls and their actions. Playfulness and innocence are equally combined in the banjo. The instrument's African origin associates the topless banjo player with a pre-Fall, pre-sin and non-Biblical female in a natural environment. Sin, as in the Bible, remains in the eye of the beholder, not the video. Two animals serve as propos, a sheep and a stuffed female dog. A female dancer holds a sheep in her arms at the beginning of the video. The sheep seems to suggest a symbol of sanctity and innocence, evoking the lamb of God as symbol for Jesus. Hence, the choreography and the prop follow traditional post-Fall female roles as chastise, shameful, modest, and fertile. He suggests such a reading because the sheep is not used in any blasphemous choreography, unlike the stuffed dog. The lyrics blast the word "bitch", hence the audience associates the stuffed dog with a bitch. Similar to the artist Madonna Ciccione, the dancer Emily claims the term and the action for women in the video. Owning sexuality and terminology, Emily proceeds to ride the bitch, thus debunking male fantasy, practice, and sexuality. The derogatory signified has successfully been replaced by a female owned and applied signifier.

Towards the end of the video, the audience is presented with a needle in Emily's bottom, which has also been the playground for a toy car, and a stop sign. The car symbolizes the power of the phallus and indeed suggests a comparison of women with toys. Multiple interpretations of the phallic object in Emily's bottom permit the association of botox as beautifying measure, but also a drug in order to rape her. Another interpretation suggests anal intercourse, which is rejected by the girl, in form of the phallic stop sign. Rather than passively pleasing her man, the female dancer does not want to be deprived of vaginal intercourse with the promise of orgasm. The Biblical Virgin Mary, symbolized in the lyrics as "good girls", is denied the full pleasures of human sexuality. The same reading might be applied to the lyrics:

Ok now he was close, tried to domesticate you

But you're an animal, baby, it's in your nature 
Just let me liberate you//hey, hey, hey

You don't need no papers//hey, hey, hey

That man is not your maker.

If they capitalize the personal pronoun "he", the Biblical connotation becomes apparent. He, in other words God, tried to domesticate you. The Latin domus relegates women away from the public arena into the subservient role of mothers and housewives. Women can only free themselves by disclaiming God as their maker, since "That man is not your maker". The refrain "I know you want it" as well as the exclamation "hey" is repeated three times, mocking the Christian Trinity and their oppressive social values. Sexual pleasure is as much "in your nature" in women, as in Catholic priests, who too are condemned to an unnatural life without sexual pleasures. Nate Jones (2013) interprets the lyrics as a "fairly progressive point-a lot of dudes are still uncomfortable with the idea that women want sex as much as men do". The video, however, grants good girls the right to pleasure by operating outside of Christian norms, in which the virgin is left with the pain of childbirth but without the pleasure during conception. Moreover, British born model Emily Ratajkowski licks her lips, preparing apparently to perform fellatio, as Robin Thicke sucks on a lit cigarette.

Undoubtedly, the choreography and the lyrics of the video operate outside of post-Fall norms for women, and the video might therefore be criticized. However, if they read the video in a larger context by focusing on the main female model, a more varied interpretation might be suggested. Emily Ratajkowski is no prude as she poses seductively in the current Frederick's of Hollywood lingerie campaign. Emily herself leaves narrow female norms behind, as she shares her motivation: "Basically, I want to be successful in this industry" (Greene, 2013). Moreover, Robin Thicke, a happily married goody two shoes of Hollywood, according to Tricia Romano (2013), does not have the reputation of a bad boy and has no rape or harassment history. Elizabeth Plank(2013), however, argues that Thicke's clean reputation makes the message more dangerous: "Yes. Men who respect women are the 'perfect' people to degrade them! Like they say, it's funny! Cause this way, women never know who they can trust. Rather than violating women, Thicke's intention was to question the arbitrary social parameters:

"We pretty much wanted to take all the taboos of what you're not supposed to do-bestiality, you know, injecting a girl in the bum with a five-foot syringe - I just wanted to break every rule of things you're not supposed to do and make people realize how silly some of these rules are” (Romano, 2013).

A superficial interpretation of the title "Blurred Lines" oscillates between rape and consent. But the title also marks the blurred lines between good girls, or virgin Madonnas, who are not allowed to want it, and girls, who, if they want it, are labeled as whores. This idea is reflected in the song as follows:

I know you want it

I know you want it

I know you want it

But you're a good girl

The way you grab me

Must wanna get nasty

Go ahead, get at me

The goal of the virgin-whore dichotomy is to withhold sexual pleasure from women. Good Christian girls, who want it but believe in the sanctity of the hymen, might end up seeking permissible pleasure in sodomy. 
Anal intercourse leaves the hymen intact and preserves the myth of the Virgin Mary, whose motherhood is solely based on the remainder of her hymen. Robin Thicke permits women the right to sexual pleasure since his intention was: "blurring the lines between men and women and how much we're the same" (Chen, 2013).

Finally, the blogger Meryl Branch-McTiernan (2013) describes passing by a Lutheran church with the billboard inscription: "God loves everybody, even Miley". What dawned on Branch-McTiernan was the equation of sin and woman. Miley Cyrus had not committed a crime. A preconceived concept of immorality is, after all, not illegal:

“The 'friendly' church was slut-slamming this young woman. We were back to the story of Eve as temptress in judging the 20-year-old who dared to act naughtily with her 36-year-old dance partner. She was someone who God was kind enough to love despite her sins” (Branch-McTiernan, 2013).

The singer and artist Madonna Ciccone successfully erased the blurred lines between virgin and whore as well. Ciccone's image as whore rejects post-Fall assigned morals by fulfilling her sexuality away from Biblical norms.

Biblical sexuality, that finds fulfillment only in the other, rather than in the self, invites an establishment of inter-gender dependencies that can easily become an instrument of religious abuse. By creating her own authority outside of established definitions, through postmodern autoeroticism, Madonna overcomes the gender hierarchy. The theme of the song "Secret" in her 1994 album Bedtime Stories - happiness lies in your own hands - is a confirmation of a gender free self-realization outside of sin and shame. Madonna's intention in her visual texts is to deconstruct male dominated, Christian thinking. She straightens out the course of intercourse by applying feminine theories in form of a historical role model, such as Evita Perón, rather than following the religious female archetypes of Eve and Mary. Madonna justifies her love and thoughts about the politics of sex, gender, and her book Sex in an interview with Chris Heath.

"Because I felt our culture is inundated with sexual fantasies, and I wanted to do something from a female point of view. I knew everybody would buy the book Sex to see naked pictures of me, but I thought people would read the text and understand the irony in a lot of it, and try to see life from a different perspective” (Heath, 1994, p. 184).

Without objectifying women, the video "Blurred Lines" and Madonna try to offer sexual pleasure for women. On the surface, Madonna is every male's wet dream. Unlike the mother of God Madonna, Madonna Ciccone creates the image of being the incorporation of eroticism and sex. What appears to be male pleasing is, however, male teasing since Madonna's body, including her sexual climax, belongs to herself. Consequently, her socio-sexual behavior becomes political. Ruth Conniff (1991) believes that "Madonna's politics, it turns out, amounts to asserting her right to masturbate on stage” (p. 17). To masturbate on stage is a political statement, and it is not uncommon for men to deny women this natural freedom, since such a behavior threatens traditional gender definitions. Ben Spiecker(1992), for example, thinks that "masturbation is a less complete sexual act, and therefore inferior" (p. 75). Madonna places emphasis on beauty and sex appeal, but her body-awareness and her physique are an expression of personal self-acceptance, rather than a response to an androcentric phallic idolization, reserved only for holy matrimony. Madonna's social message therefore is a political massage that can best be described as an "I-do-it-myself-sexuality", or masturbation on stage beats penetration in private. Such action reestablishes a pre-Fall understanding of shameless sexuality for women.

Madonna's sexual approach is subversive, denying and rejecting marriage, as well as the heterosexual nuclear family. John Fiske (1989) comments "that marriage is a patriarchal institution and as such is threatened 
by Madonna's sexuality”(p. 99). Questioning male authority by revoking the basic form of male heterosexual pleasure, as Joseph Sobran (1991) deplores, heterosexual men are "naturally" threatened by Madonna's liberation: "Real love is like art: It demands subordination of the ego. Kinky, exciting, shocking: These are the attributes of love as she conceives it. The purpose of this love is neither permanent union nor procreation, but pleasure and ego-enhancement (p. 35). Sobran's views on sexuality can best be described as being romantic. Antony Easthope(1990), however, points out that romantic love, expressed by Sobran as "the yearning for union", aggressively reduces the mistress to a slave repeating "the version of masculine mastery concealed inside the male lover's seeming subservience" (p. 145). Indeed Sobran's real love calls for "the subordination of the ego" for the purpose of "permanent union" and procreation at the cost of a painful childbirth. Thus love is an expression of male power over the woman, such as the Virgin Mary — denying her any kind of pleasure by which "her essence and her desire is the complement of his - that is, subordinate" (Easthope, 1990, p. 149).

Psychologically, masculinity in general and male power in particular are connected to the phallus. According to Easthope (1990), masculinity “...can be represented as active in having the phallus on condition that the feminine is passive in being the phallus” (p. 150). By touching her crotch and thus checking her phallus by way of a typically male gesture, Madonna signalizes on the one hand that she has the phallus. In the video "Express Yourself" for example Madonna appears to be a heterosexual, masculine - that is phallus-owningfemale. On the other hand, she personifies the passive, male pleasing torpedo-bra-lingerie-phallus in videos such as "Like a Virgin". Yet as soon as Madonna appears to be most male pleasing, she directs her sexual appeal away from male desires, instantly turning into an auto-sexual, or bisexual, feminine non-phallus-owning - female. Hence the male viewer receives two contradictory psychological messages from his object of desire: First, the female represents the passive phallus that is worth desiring. Next, she actively signals that she also has the phallus. To desire the phallus, however, is a taboo for the heterosexual male, since such a desire is clearly associated with homosexuality. Consequently, Madonna's self-acquired phallus is the object of power since it "serves to represent [male] sexuality" (Easthope, 1990, p. 118). The dancer Emily in "Blurred Lines" points to Robin Thicke's crotch with a glove. Its oversized index finger indicates that Emily, like Madonna, owns and uses the phallus, whenever it pleases her.

Finally, Madonna subversively incorporates the main threats to masculinity: homosexuality and femininity. Easthope (1990) elucidates the social principle of the masculine hege-man-y as follows: Masculinity "must control what threatens it both from within and from without. Within, femininity and male homosexual desire must be denied; without, women and the feminine must be subordinated and held in place” (p. 166), in order to keep the current gender status quo. Madonna, at times, deliberately appears to follow stereotypical behaviorisms, allowing for her heterosexual male viewers to indulge in their fantasies. Adam had been granted such sexual fulfillment with his first partner Lilith, and the pre-Fall Eve. Simultaneously, Madonna attracts a multi-sexual and bi-gender audience that, in an equally voyeuristic manner, witnesses Madonna's pleasures. At this point, it becomes obvious that Madonna's self-satisfaction is not intended for one particular group, but herself. Thus E. Ann Kaplan (1987) describes Madonna's self-creation as follows: "Madonna represents the postmodern feminist heroine in that she combines unabashed seductiveness with a gutsy kind of independence. She is neither particularly male nor female identified, and seems mainly to be out for herself (p. 126), and Lawrence Grossberg (1991) adds to Madonna's postmodern identity that it doesn't matter what image one takes; take any image and live it for as long as you want” (p. 228). Inverting the sexual objectification of women by decon-sex-ualizing the arbitrary social gender definitions, Madonna demonstrates that there should not be any 
penetration for procreation, but for pleasure.

Madonna's most erotic music videos demonstrate an anti-Biblical sexuality that is presented in a visual middle-class heteromock performance. In an interview she challenged heterosexual men by annihilating once again the cultural notion of masculinity: "Effeminate men intrigue me more than anything in the world. I see them as my alter egos. I feel very drawn to them. I think like a guy, but I'm feminine. So I relate to feminine men” (Meisel, 1991, p. 200). It seems that Camille Paglia shares her own sexual fantasies, rather than Madonna's, in the following quotation: "Madonna loves real men. She sees the beauty of masculinity, in all its rough vigor and sweaty athletic perfection” (Paglia, 1992, p. 5). But doesn't Madonna ridicule men even more by surrounding herself with perfectly sculptured males - bodies most of her male voyeurs can only dream offin order not to sexually desire these men? In the video "Express yourself" men are seen as erotic, however Sisyphean, objet d'art, and not as actual sexual partners. This assumption is supported by the fact that most dancers in the Blond Ambition tour are gay.

The fact that Madonna is a successful pop artist and prosperous businesswomen is equally disturbing to men. Unlike a virgin, Madonna not only survives in the male business world, but she aggressively outdoes males. The Madonna successfully left Eden without giving up the right to sexual pleasures.

Madonna preaches and practices an "I-do-it-myself-sexuality", becoming the self-enjoying virgin. "For Christians, the dignity of Mary is the norm for the dignity of womanhood. That is, virginity, maternity, and faith are women's dominant callings” (Hume, 1991, p. 10). Thus Madonna and Mary, the mother of God, not only have an alliteration in common, but they also share a non-male, nor-female-oriented sexuality, in which Madonna slips into the self-sufficient, solipsistic woman. In National Times she confessed: "When I was tiny, she recalls, 'my grandmother used to beg me not to go with men, to love Jesus and be a good girl. I grew up with two images of women: the virgin and the whore. I was a little scary” (Madonna, 1985, p. 5). Madonna's fear is justified, according to Fiske(1989), since both terms whore and virgin are male centered, and depend on a male judgment.

"Madonna calls into question the validity of these binary opposition as a way of conceptualizing woman. Her use of religious iconography is neither religious nor sacrilegious. She intends to free it from this ideological opposition and to enjoy it, use it, for the meanings and pleasure that it has for her, not for those of the dominant ideology and its simplistic binary thinking” ( p. 103).

Hence, Madonna achieves a meta-understanding of the signified, and creates a meta-language independent of the signifier in which the crucifix becomes an object of decoration rather than adoration.

"These freed signifiers do not necessarily mean something, they do not acquire new signifieds; rather, the act of freeing them from their ideological context signifies their users' freedom from that context. It signifies the power of the subordinate to exert some control in the cultural process of making meanings" (Fiske, 1989, p. 107). A close reading of the opening lines of her song "Like a Virgin” from her album The Immaculate Collection, and the video version from the movie Truth or Dare will support this argument.

I made it through the wilderness

Somehow I made it through

Didn't know how lost I was

Until I found you

I was beat 
Incomplete

I’d been had, I was sad and blue

But you made me feel

Yeah you made me feel

Shiny and new

Like a virgin

Touched for the very first time

Like a virgin

When your heart beats next to mine

Gonna give you all my love boy

My fear is fading fast

Been saving it all for you

Cause only love can last. (Fiske, 1989, p. 108)

The song miraculously combines such opposites as spirituality versus carnality, the male gaze versus the female look, and the virgin versus the whore. The first four lines of the song are dominated by a male spirituality, emphasized by the verb "know" and the theme evoked in the lines, a male Jesus. As John Fiske(1989) points out, the song relies on Biblical allusions and language. The first line "I made it through the wilderness” associates Jesus temptations in the desert. Madonna, as a woman, claims Jesus' experience for herself. The lines "Didn't know how lost I was/Until I found you” also play with the Christian idea of being lost like a sheep and achieving salvation by finding God, who has traditionally been portrayed as being male. The next three lines, "I was beat/Incomplete,/ I'd been had, I was sad and blue”, focus on a female existence of physical, verbal, even sexual abuse by men.

While men are associated with spirituality in the first part of the song, women are described as carnal objects. Madonna confessed in an interview "I like boys-15 or 16 year olds are the best. I like them smooth and thin. I want to caress a nice smooth body not a hulk”. Boys are less threatening and less virile than post-pubescent men. By preferring boys, she rejects male sexuality and the male body, of which she has been a victim as the line "I was beat" underlines, and she turns around the male-female roles of sexual behavior. In Madonna's "Like a Virgin", it is the mature woman who is aggressive and sexually experienced. Furthermore, the line "Been saving it all for you" assumes a male speaker biologically, not a female one. Once again, Madonna alters sexual signifiers and their cultural definitions. The same is true for the line "Gonna give you all my love boy" in the following stanza.

Madonna's self-fulfillment, however, does not lie in finding an external course, such as God or a male mate, rather she moves inwardly, into herself. Madonna makes the emphasis on the self very clear through the accumulation of the personal pronoun $I$, which occurs no less than seven times in the first ten lines. The first two thirds of the stanza are entirely focused on her, and it is not before the eighth line that the focus shifts to the personal pronoun you. The last three lines "But you made me feel/ Yeah you made me feel/ Shiny and new", could be read as a female submission and a male objectification of the woman. The female verb "feel" of the eighth and ninth line is in opposition to the male verb "know" of the third line. But by the ninth line in the song the knowing, spiritual male, introduced as a you, appears verbally weak, and almost non-existent, since Madonna has already linguistically established her personality in the preceding seven lines. The text specifically mocks male dominance, replacing it with a verbally established female existence. 
The same is true for the simile "like a virgin". By definition virginity is a medical and social condition that is related to sexual penetration, and social classification. This male based classification of women is "just like a burden. I think all girls feel that way” (Heath, 1994, p. 135), says Madonna in a Details interview. She got rid of this social stigma by losing her virginity at the age of 15 to a boy called Russell Long. Madonna's recollection of this event is matter-of-fact. Asked how she felt after having had intercourse for the first time, she answers: "Like I had just gotten off a horse. And I had to go back to French class" (Heath, 1994, p.135). By using the simile "like a virgin", Madonna creates the allusion of reproducible virginities. She thereby destroys the definition and the gender-related power of the signifier, such as much as Emily claims the term "bitch" by riding a bitch in the video "Blurred Lines". Greta Gaard(1992) calls the Madonna video a gender-bender deluxe, forcing the viewer "to look more and to look carefully" (p. 44). The song eventually picks up speed in the f-alliterating line "My fear is fading fast", implying orgasm. On stage, the male dancers disappear, allowing for Madonna to enjoy herself like a virgin.

\section{Conclusion}

Almost one generation between Madonna and Emily has blurred the lines of sexuality and sexual identity for women and men alike. Madonna used visual stimuli effectively in her videos in order to free herself from male domination. Her goal was a penetration for pleasure, not procreation. Emily's generation grew up in a virtual world. Inundated with sexual messages, the Millenium generation has experienced almost any type of penetration in cyber space. Such visual sexual engagement opened the door for an alternative, more accepting and tolerant understanding of gender and sexuality. Lacking heroine status in video games, Eve and Mary have become void reference points for the Milleniums.

Nevertheless, "Blurred Lines" and Madonna's videos are rites of passage, portraying a cathartic experience and woman's journey back to a pre-Fall sexuality. While the respective audience associates the female artists with their own sexual symbols, these artists turn away from Biblical conventions. Madonna achieves self-realization by consciously buying into the religious Madonna myth. The female dancers in "Blurred Lines" reject any association with Eve or Mary. Their performance celebrates a sexuality without shame. The Virgin Mary, as symbol of purity, is debunked and redefined by the female artists. Meaning is redistributed among signifiers by deconstructing and redefining conventional signifiers of a Christian culture, such as virgin and whore.

\section{References}

Aglialoro, Todd M. (2009, October 6). The new Catholic manliness. Retrieved from http://www.catholicculture.org/culture/library/view.cfm?recnum=7865

Branch-McTieernan, Meryl. (2013). Blurring my lines. http://www.huffingtonpost.com/meryl-branchmctiernan/blurring-my-own-lines_b_3922537.html

Brown, Jane D., \& Schulze, Laurie. (1990). The effects of race, gender, and fandom on audience interpretations of Madonna's music videos. Journal of Communication, 40 (2), 88-102.

Brannon, Linda. (2012). Gender Stereotypes: Masculinity and Femininity. Retrieved from http://www.google.com/url?sa=t\&rct=j\&q=\&esrc=s\&source=web\&cd=1\&ved=0CCsQFjAA\&url=http\%3A\%2F\%2Fwww.f eminish.com\%2Fwp-content\%2Fuploads\%2F2012\%2F08\%2FBrannon_ch07.pdf\&ei=lFlHU5GPL4bB0AGw0ICwCg\&usg= AFQjCNE5uZbCA0sCvo2WmEp3AAUJf2w_cQ\&bvm=bv.64542518,d.dmQ

Brunt, Rosalind, \& Grossberg, L., Nelson, C. Treichler, P. (1992). Engaging with the popular: Audiences for mass culture and what to say about them(Eds.), Cultural studies. New York and London: Routledge. 
Burgoon, Judee K., Le Poire, B. A., Beutler, L. E., Bergan, J., \& Engle, D. (1992). Nonverbal behaviors as indices of arousal. Journal of Nonverbal Behavior, 36(1), 159-178.

Chen, Joyce. (2013). Robin Thicke Slams “Blurred Lines” Criticism: “I can't even dignify that with a response”. Retrieved from http://www.usmagazine.com/celebrity-news/news/robin-thicke-slams-blurred-lines-criticism-i-cant-even-dignify-that-with-aresponse-2013107

Conniff, Ruth. (1991). Politics in a post-feminist age. The Progressive, 55(7),17-18.

Curry, Ramona. (1990). Madonna from Marilyn to Marlene-Pastiche and/or Parody? Journal of Film and Video, 42(2), 15-30.

Easthope. Antony. (1990). What a Man's Gotta Do. Boston: Unwin Hyman.

Fiske, John. (1989). Madonna. Reading the Popular. Winchester, Mass: Unwin Hyman, Inc.

Fuchs, Cynthia J., \& Grossberg, L., Nelson, C., Treichler, P. (Eds.). (1992). Desperately Seeking a Subject: Postmodern Sexuality, Seidelman, and Madonna. Sexuality, the Female Gaze, and the Arts. London: Susquehanna University Press.

Gaard, Greta. (1992). The Laugh of Madonna: Censorship and Oppositional Discourse. M/MLA, 25(1), 41-44.

Gow, Joe. (1992). Making Sense of Music Video: Research During the Inaugural Decade. Journal of American Culture, 15 (3), $35-43$.

Gow, Joe. (1992). Music Video as Communication: Popular Formulas and Emerging Genres. Journal of Popular Culture, 26(2), 41-70.

Grossberg, Lawrence. (1992). We Gotta Get out of this Place. New York: Routledge.

Harris, Daniel. (1992, June 8). Make My Rainy Day (pp.790-793). The Nation.

Heath, Chris. (1994, December). The Madonna Complex (pp.130-139). Details.

Hegstrom, Jane L., \& Griffith, W.I.. (1992). Dominance, Sex, and Leader Emergence. Sex Roles, 27 (5/6), 209-220.

Hume, Maggie. (1991). The status of women. Conscience, 12(6),1-11.

James, Caryn. (1992, October 25). The Empress has no clothes. New York Times Book Review, 7.

Kaplan, E. Ann. (1987). Rocking Around the Clock. New York: Methuen.

King, Chris Savage. (1992, October 23). Justify her love (pp.33-34). New Statesman \& Society.

Mailer, Norman. (1994, August). Norman Mailer on Madonna: Like A Lady. Esquire, 41-56.

Marcel. (2010, March 5). “The Death of Masculinity.” Retrieved from http://www.creativeminorityreport.com/2010/03/death-of-masculinity.html

Mason, Gary. (2013, September 13). "Blurred Lines, blurred Morals.” Retrieved from http://www.theglobeandmail.com/commentary/blurred-lines-blurred-morals/article14302377/

Meisel, Steven. (1991, April). The Misfit. Vanity Fair, 158-169.

Michaels, Sean. (2013, September 13). “'Blurred Lines’ banned by Edinburgh University.” Retrieved from http://www.theguradian.com

Morales, Beatriz, \& Weaver, T. (Ed.). (1994). "Latino Religion, Ritual and Culture.” Handbook of Hispanic Cultures in the United States: Anthropology. Houston: University of Houston Arte Publico Press, vol. 4, National Time (1985, August 23/29), 9.

Madonna: Close up and Personal. (1985). London: Rock Photo Publications.

Ocampo, Anthonly. (2012). “Making Masculinity: Negotiataions of Gender Presentation among Latino gay Men.” Latino Studies, 10 (4), 448-472.

Ortner, Sherry, \& Whitehead, Harriet. (1981). Sexual Meanings. The Cultural Construction of Gender and Sexuality. Cambridge: Cambridge University Press.

Ortiz, Fernando A. (2012, November 7). "Machismo and Masculinity in the Latino Culture." Retrieved from http://fernandoortiz.blogspot.com/2012/11/machhismo-and-masculinity.html

Paglia, Camille. (1992). "Madonna I: Animality and Artifice." Sex, Art, and American Culture. New York: Vintage Books.

Patton, Cindy, \& Schwichtenberg, C. (Ed.). (1993). "Embodying Subaltern Memory: Kinesthesia \& the Problematics of Gender \& Race." The Madonna Connection. Boulder: Westview Press.

Plank, Elizabeth. (2013, July 24). “A Feminist Takedown of Robin Thicke, And Anyone Who Thinks There’s Something 'Blurry' AboutSexism.”Retrieved

from http://www.policymic.com/articles/56069/a-feminist-takedown-of-robin-thicke-and-anyone-who-thinks-there-s-something-bl urry-about-sexism

Romano, Tricia. (2013, June 17). “'Blurred Lines,' Robin Thicke’s Summer Anthem, Is Kind of Rapey.” http://www.thedailybeast.com/articles/2013/06/17/blurred-lines-robin

Rubey, Dan. (1991). "Voguing at the Carnival: Desire and Pleasure on MTV.” The South Atlantic Quarterly, 90 (4), 871-906.

Sante, Luc. (1990, August 27). "Unlike A Virgin.” The New Republic, 25-29.

Shewey, Don. (1991, May 7). "Madonna: the Saint, the Slut, the Sensation.” Advocate, 42-51. 
Sobran, Joseph. (1991, August 12). Madonna. National Review,32-35.

Spiecker, Ben. (1992). Sexual Education and Morality. Journal of Moral Education, 55 (7), 67-76.

Stewart, Cynthia.(n.d.).“Gender and Sexuality.” $\quad$ Retrieved from http://www.paatheos..com/Library/Roman-Catholicism/Ethics-Morality-Community/Gender-and Sexuality.html.
"Blurred
Lines."
(2013,
September
25).

http://www.google.com/url?sa=t\&rct=j\&q=\&esrc=s\&source=web\&cd=1\&ved=0CCgQFjAA\&url=http\%3A\%2F\%2Fen.wiki pedia.org\%2Fwiki\%2FBlurred_Lines\&ei=h1VHU4HdLoSI0AHugYG4Cw\&usg=AFQjCNF8GY9XIJuljgMF8_905pb0D3-lw\&bvm=bv.64542518,d.dmQ

van den Haag, Ernest. (1960). “A Dissent from the Consensual Society.” Daedalus, Spring, 316.

von Hallberg, Robert. (1985). American Poetry and Culture, 1945-1980. Cambridge: Harvard University Press.

Retrieved from WordReference.com English-Spanish Dictionary. http://www.wordreference.com, 2014. 